Crop Breeding and Applied Biotechnology 13: 363-366 2013

Brazilian Society of Plant Breeding. Printed in Brazil

\title{
NOTE
}

\section{Induced desynaptic variation in poppy (Papaver somniferum L.)}

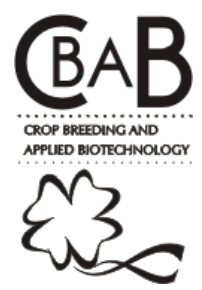

\author{
Sana Naseem ${ }^{1 *}$ and Girjesh Kumar ${ }^{1}$
}

Received 18 May 2012

Accepted 30 October 2013

\begin{abstract}
Cytological investigation of EMS (ethyl methane sulphonate) treated population demonstrated enhanced univalent frequency per cell with unequal separation at Anaphase I. In contrast to controlled plants, medium strong type desynaptic plants were obtained from $0.6 \%$ EMS treated set, revealing high frequency of univalents at Metaphase I, along with bivalents, which were loosely paired. The univalents remained unpaired till the end of meiosis, leading to formation of micronuclei and abnormal tetrads. These plants had high pollen inviability and sterile seeds. It might be possible that EMS had acted on some genes responsible for chiasma formation, resulting in early chiasma dissociation, which suggests that EMS can act as a potential tool in the development of male sterile lines. The study demonstrated the feasibility of chemical mutagenesis in mutation breeding programme on poppy (Papaver somniferum L.).
\end{abstract}

Key words: Desynapsis, ethyl methane sulphonate, Papaver somniferum.

\section{INTRODUCTION}

Meiosis is a specialized differentiation process that generates recombinant haploid gametes from a diploid zygote (Pankratz and Forsburg 2005). Meiotic recombination has been frequently analysed through cytological and genetical methods. Several genes are essential for encoding proteins required for pairing and synapsis, or are involved in catalyzing key steps in DNA breakage, repair and recombination (Roeder 1997,Zickler and Kleckner 1999). Mutation in the genes directing meiotic recombination may cause failure or early termination of chiasma formation. Atleast one chiasmata per bivalent is essential for orderly disjunction, otherwise, some homologues may migrate to same pole and form aneuploid gametes. The absence or failure of synapsis is termed as asynapsis, whereas the immediate separation of the homologues following normal pachytene pairing is specified as desynapsis (Gottschalk and Kaul 1980a, b).

Both spontaneous and induced types of desynapsis have been reported in different plant species like Pennisetum ramosum (Jauhar et al. 1971), Zinnia haegena (Singh and Gupta 1981), Capsicum annum (Rao and Kumar 1983), Hordeum vulgare (Srivastava 1974, Kumar and Singh 2002), Oryza sativa (Reddi and Rao 2000), Cicer arietinum (Kumar and Sharma 2001), Anogeissussericea (Rao and Kumar 2003), Glycine max (Palmer and Horner 2000, Bione et al. 2002, Kumar and Rai 2006), Corchorus fascicularis (Maity and
Datta 2009). Thus, desynapsis is an important cytological phenomenon and desynaptic plants offer possibility for the production of aneuploids (Soost 1951, Burnham 1962).

Poppy is a plant of immense pharmaceutical importance highly valued for its alkaloids namely morphine, thebaine and codeine. India accounts for 70 percent of the total world production and trade of opium. The present study is an attempt to understand the genetic behaviour of desynaptic mutants through cytogenetic analysis as our knowledge on this facet is inadequate in the case of Papaver somniferum L. Study of desynapsis is a potentially important source of information on the chiasma maintenance mechanism and a possible source for aneuploid production. Furthermore, such study can provide useful cytological and genetic information on the male sterility that occurrs in higher plants.

\section{MATERIAL AND METHODS}

Seeds of locally adapted inbred line of Papaver somniferum L. viz. Vivek were obtained from CIMAP (Central Institute of Medicinal and Aromatic Plants), Lucknow. Dry and healthy seeds of $P$. somniferum were standardized for approximately $12 \%$ moisture content and were pre-soaked in distilled water. After $12 \mathrm{~h}$ of pre-soaking, they were treated with ethyl methane sulphonate (EMS) at 3 different concentrations $(0.2 \%, 0.4 \%$ and $0.6 \%)$, which were prepared in sodium phosphate buffer with $7.0 \mathrm{pH}$ for $6 \mathrm{~h}$ with con-

\footnotetext{
${ }^{1}$ University of Allahabad, Department of Botany, Plant Genetics Laboratory, Allahabad-211002, India.*E-mail: sana.naseem3@gmail.com
} 
stant shaking(FAO/IAEA Technical Report Series No. 119, 1977). The treated seeds were thoroughly washed in running tap water for 30 min to remove the residual effect of the mutagen stuck to the seed coat. One set of seeds was kept untreated to act as control. The treated seeds along with the control seeds were sown immediately in the field at the Experimental Research Farm of CIMAP Lucknow, India, under standard agronomic practices. The M1 Seeds were laid out in 3 replicates for each dose along with control seeds, adopting the randomized complete block design (RCBD).

For meiotic studies, young floral buds about to emerge from the sheath were fixed in freshly prepared 1:3 acetic alcohol solution (Carnoy's fixative) in which acetic acid component was saturated with ferric acetate. The buds were kept for $24 \mathrm{hrs}$ in the fixative, and after that, they were passed to and preserved in $70 \%$ alcohol at $4^{\circ} \mathrm{C}$. Slides were prepared using another squash technique with $2 \%$ acetocarmine. More than 500 dividing PMCs from all treatment sets, as well as from control populations, were studied and analyzed. All phases of meiosis were evaluated, starting from diakinesis. Meiotic configurations were observed in metaphase I and anaphaseI. Prakken (1943), on the basis of univalent frequency, divided the desynaptic mutant into weak, medium strong and strong types: weak, with few univalents in some of the cells; medium strong, with many univalents in most of the cells; and strong with univalents only, or some rare bivalents. Thus, taking into account the frequency of univalents found at metaphase I, it could be said to be of medium strong type.Pollen grains were also stained with $2 \%$ acetocarmine to study pollen fertility; undersized and unstained pollen grains were considered inviable. Slides were analyzed and suitable cells were photographed under Nikon research photomicroscope.

\section{RESULTS AND DISCUSSION}

The cytological studies of population raise of $0.6 \%$ EMS treated seeds revealed that 6 plants had abnormal meiotic behaviour and were found to be desynaptic. In the case of control population, meiosis was found to be normal with regular occurrence of 11 bivalents $(2 \mathrm{n}=22)$ at diakinesis (Figure 1A) and normal 11:11 segregation at anaphase I (Figure 1B).However, only few PMCs showed complete bivalent formation in the desynaptic plants (Figure 1C to $1 \mathrm{~J}$ ) and highly unequal and irregular distribution of chromosomes (Figure1K and 1L). The chromosomal configurations at diakinesis/metaphase I and different types of anaphase I separations are presented in Table1.

The univalents found in desynapsis have a tendency to be in mutual dependence of position. Univalentsin the same pair were found arranged close to each other. The close proximity of univalents and the arrangement of chromosomes
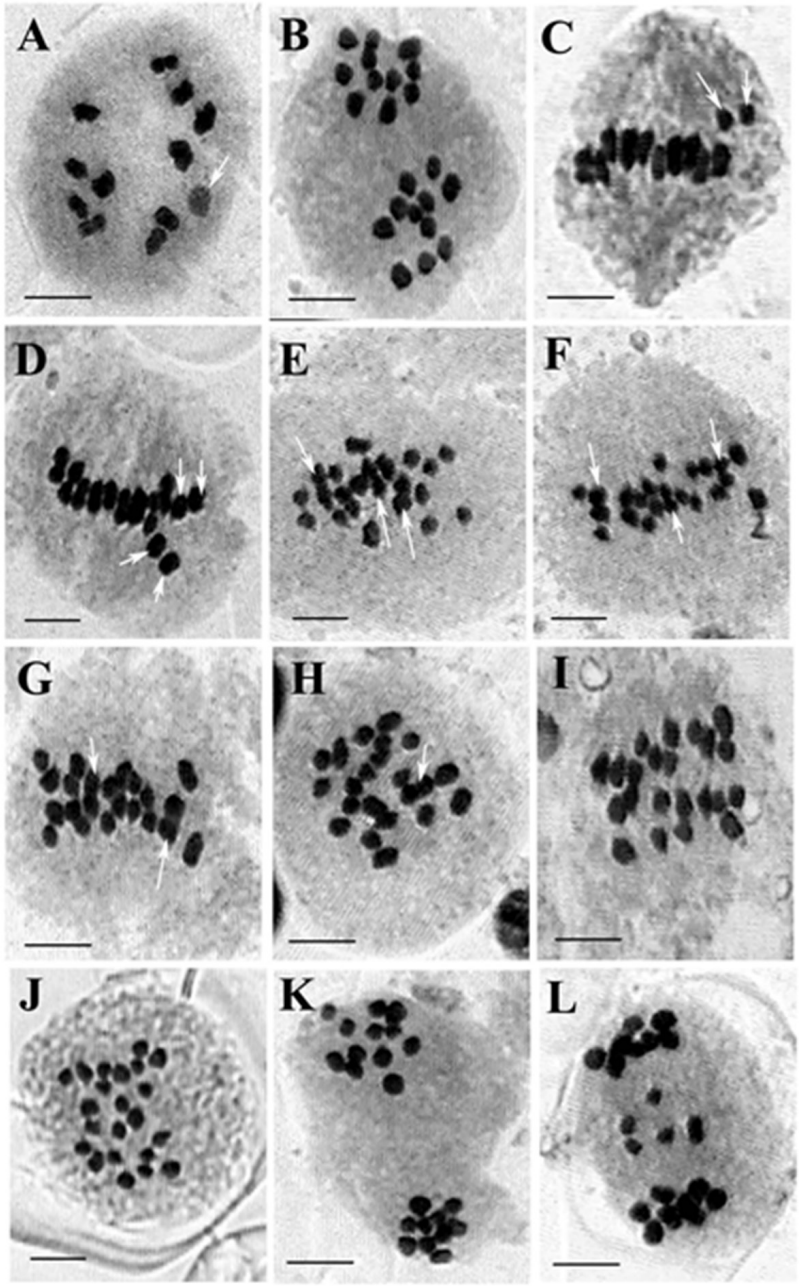

Figure 1. Meiosis in desynaptic plants. A. Diakinesis ( $\mathrm{n}=11$; arrow showing nucleolus); B. Anaphase I (11:11 separation); C. Metaphase I (10 II+2 I; arrow showing 2 univalents); D. Metaphase I (9 II+4 I; arrow showing 4 univalents); E. Metaphase I (4 II+14 I; arrow showing 4 bivalents); F. Metaphase I (3 II+16 I; arrow showing 3 bivalents); G. Metaphase I (2 II+18 I; arrow showing 2 bivalents); H. Metaphase I (1 II+20 I; arrow showing 1 bivalent); I. Irregular arrangement of univalents at equatorial plate; J. Metaphase I (22I); K. Unequal separation at anaphase I (12:10); L. Anaphase I with 5 lagging chromosomes. (Scale bar: $4.2 \mu \mathrm{m}$ )

at the metaphase plate suggested a very recent dissociation. According to Peirson et al. (1997), in asynaptics, univalents never align at the equator at metaphase I, whereas in desynaptics, the bivalent, as well as univalents, congregate at metaphase plate. This suggests that the present mutants are of desynaptic type. At times, univalents were scattered irregularly in the PMCs. Due to unorientation and irregular arrangement of univalents at equatorial plate, there was no clear cut distinction of metaphase I and anaphase I (Figure 1I). Such anomalies lead to unequal separation and laggards at anaphase I. In some cases, 22 univalents were found at metaphase (Figure 1J). Presence of a large number of PMCs 
Table 1. Configurations at diakinesis/metaphase I and segregations at anaphase I in induced desynaptics plants of Papaver somniferum L. viz. Vivek

\begin{tabular}{|c|c|c|c|c|c|c|c|c|c|}
\hline \multirow{2}{*}{$\begin{array}{l}\text { Plant } \\
\text { No. }\end{array}$} & \multirow{2}{*}{$\begin{array}{l}\text { Total PMCs } \\
\text { observed }\end{array}$} & \multicolumn{4}{|c|}{ Diakinesis/Metaphase I configurations (\%) } & \multicolumn{2}{|c|}{ Segregations at Anaphase I (\%) } & \multirow{2}{*}{$\begin{array}{l}\text { Total Ab- } \\
\text { normality } \\
(\%)\end{array}$} & \multirow{2}{*}{$\begin{array}{l}\text { Pollen } \\
\text { invi- } \\
\text { able } \\
(\%)\end{array}$} \\
\hline & & $11 \mathrm{II}$ & $\begin{array}{l}(8-10) \\
\mathrm{II}+(6-2) \mathrm{I}\end{array}$ & $\begin{array}{l}(4-7) \\
\mathrm{II}+(14-8) \mathrm{I}\end{array}$ & $\begin{array}{l}(0-3) \\
\mathrm{II}+(22-16) \mathrm{I}\end{array}$ & $\begin{array}{l}\text { Unequal Separation } \\
(10: 12,8: 14,6: 16)\end{array}$ & $\begin{array}{l}\text { Laggards } \\
(1,2,3,5)\end{array}$ & & \\
\hline 1 & 530 & 3.37 & 11.66 & 22.62 & 22.21 & 13.44 & 15.45 & 88.75 & 84.20 \\
\hline 2 & 516 & 3.62 & 15.58 & 18.69 & 24.50 & 12.16 & 15.73 & 90.28 & 86.04 \\
\hline 3 & 562 & 3.68 & 11.46 & 21.06 & 20.34 & 12.20 & 17.10 & 85.84 & 80.56 \\
\hline 5 & 510 & 4.55 & 12.80 & 22.14 & 25.30 & 13.32 & 14.22 & 92.33 & 87.15 \\
\hline 6 & 524 & 4.71 & 12.25 & 20.83 & 19.10 & 11.40 & 13.24 & 81.53 & 76.05 \\
\hline
\end{tabular}

with univalents may be interpreted to be due to small rearrangements, particularly interstitial translocations between chromosomes, which do not involve the ends. Due to such interstitial differences, the chromosomes do not form rings or chains, but pair loosely at pachytene and desynapse at metaphase I (Stebbins 1971). Since the bivalent had 1 or 2 chiasmata, delay in chiasma terminalisation promoted the occurrence of laggards at anaphase I (Figure1L). Univalents that were not successful in their polar movements typically formed micronuclei (Figure 2A) and ultimately produced abnormal tetrads (Figure 2C), microspores of various sizes

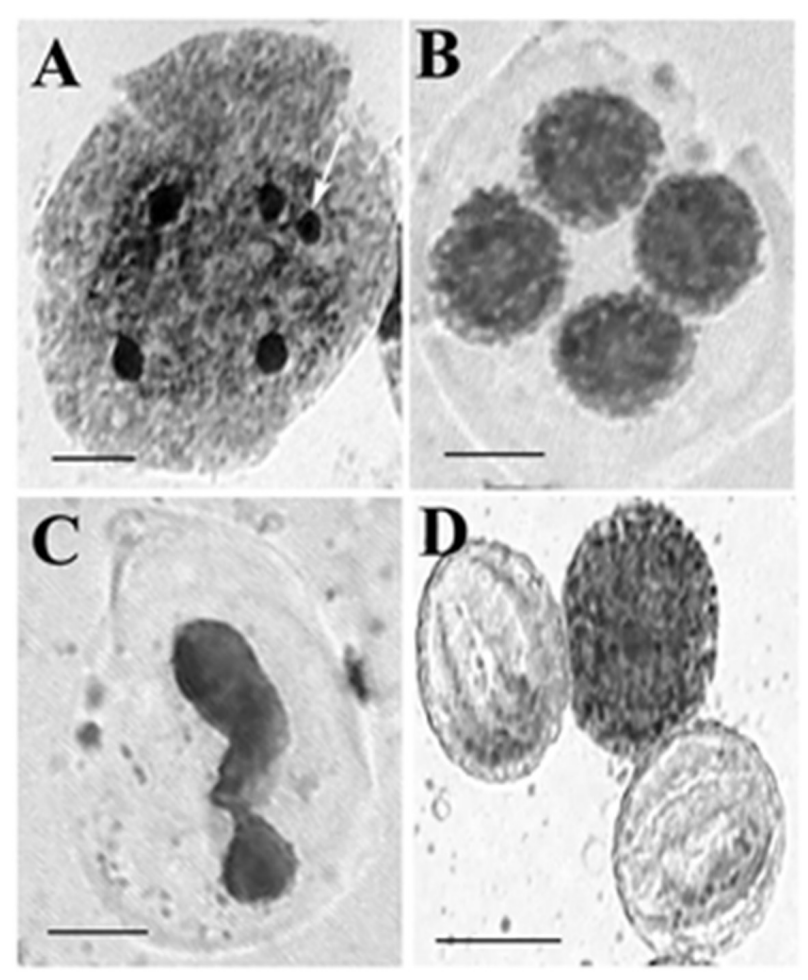

Figure 2. Meiotic by-products. A. Micronuclei at telophase I; B. Normal tetrad; C. Abnormal tetrad; D. Pollen grains: viable (dark) and inviable. (Scale bar: $4.2 \mu \mathrm{m})$ and ploidy levels that normally do not develop into viable pollen grains resulting into sterile gametophytes (Figure 2D).

The early phases of meiotic events are more prone to alterations by intrinsic or extrinsic agents. The agent in the present case was EMS, which might have acted on some genes responsible for synapsis and chiasma formation, and resulted in early chiasmate dissociation. Various theories have been suggested by different authors from time to time to explain the occurrence of desynapsis. According to Armstrong et al. (2002), the genes responsible for the formation of synaptinemal complex (SC) proteins have highly conserved sequence. A mutation in these genes might have led to defective SC proteins, which are unable to hold the homologous together for long. Ji et al. (1999) proposed that recombination modifier mutation in rec gene might reduce recombination to a point where no pairing occurs. Maguire et al. $(1993,1995)$ has emphasized that the recombination is insufficient to hold the chiasma in place. Additional factors, located either at the chiasmata or between sister chromatids are required to maintain chiasmata. Earlier workers, like Sharma and Reinbergs (1974), proposed that recessive homozygous condition of $d s$ genes might cause chiasma to dissociate early. Simchen and Stamberg (1969) concluded from their study that a mutation in highly conserved rec genes system might lead to failure of chiasma formation and recombination.

The study further provides useful cytological and genetical information about the manner male sterility occurs in higher plants. The study also shows the importance of EMS as a potential tool for development of male sterile lines in poppy, which is rare in self-pollinated crop. Thus, it can be concluded that EMS induced meiotic irregularities, like asynapsis and desynapsis, are useful in producing aneuploids in plants and male sterile lines in poppy.

\section{ACKNOWLEDGEMENTS}

Authors are extremely thankful to Prof. Ram Rajasekharan, the Director of CIMAP (Central Institute of 
Medicinal and Aromatic Plants), Lucknow, for providing the seeds and the experimental field to grow the crop. Kind help and support of Dr. Birendra Kumar, Scientist EII at
CIMAP, Lucknow, is gratefully acknowledged. Sincere thanks to all the members of Plant Genetics Laboratory for their encouragement and support.

\section{Variação desináptica induzida em papoula (Papaver somniferum L.)}

Resumo - Investigações citológicas de EMS (Etil metano sulfonato) em população tratada demonstrou frequencia aumentada de univalentes por célula com separação desigual na Anáfase I. Em contraste às plantas controladas, plantas desinápticas em meio forte foram obtidas em EMS 0,6\%, revelando alta frequência de univalentes na Metáfase I, junto com bivalentes, os quais foram pareados. Os univalentes mantiveram-se não pareados até o final da meiose, levando à formação de micronúcleos e tétrades anormais. Estas plantas tiveram alta inviabilidade de pólen e sementes estéreis. É possivel que EMS tenha atuado em alguns genes responsáveis pela formação de chiasma, resultando em dissociação, o qual sugere que EMS pode atuar como uma ferramenta potencial no desenvolvimento de linhagens macho estéril. Este estudo demonstrou a viabilidade de mutagênesis químicos no programa de melhoramento por mutação em papoula (Papaver somniferum L.).

Palavras-chave: Desinápse, etil metano, Papaver somniferum.

\section{REFERENCES}

Armstrong SJ, Caryl AP, Jones GH and Franklin FCH (2002) Asy 1, a protein required for meiotic chromosome synapsis, localizes to axisassociated chromatin in Arabidopsis and Brassica. Journal of Cell Science 115: 3644-3655.

Bione NCP, Pagliarini MS and Almeida LA (2002) Anasynaptic mutation in soybean (Glycine $\max$ (L.) Merrill) associated with total absence of sister chromatids cohesiveness. Cytologia 67: 177-183.

Burnham CR (1962) Discussion in cytogenetics. Burgess Publishing Company, Minneapolis, 375p.

Gottschalk W and Kaul MLH (1980a) Asynapsis and desynapsis in flowering plants.I.Asynapsis. Nucleus 23: 1-15.

Gottschalk W and Kaul MLH (1980b) Asynapsis and desynapsis in flowering plants.II. Desynapsis. Nucleus 23: 97-120.

Jauhar PP, Singh and Alice CJ (1971) Partial desynapsis in Pennisetum ramosum (Hochst.) Schweinf. Cytologia 36: 698-701.

Ji YE, Stelly DM, Donato MD, Goodman MM and Williams CG (1999) A candidate recombination modifier gene for Zea Mays L. Genetics 151: 821-830.

Kumar G and Rai P (2006) Induced desynaptic male sterile lines in soybean. Cytologia 71: 337-343.

Kumar G and Sharma V (2001) Induced desynapsis in Cicer arietinum L. Journal of Cytology and Genetics 2: 123-127.

Kumar G and Singh V (2002) Desynaptic variation in barley. Journal of Cytology and Genetics 3: 127-131.

Maguire MP, Paredes AM and Riess RW (1993) Sister chromatid association at meiosis. Maydica 38: 93-106.

Maguire MP, Paredes AM and Riess RW (1995) Is the synaptonemal complex a disjunction machine? Journal of Heredity 86: 330-340.

Maity S and Datta AK (2009) Spontaneous desynapsis in Corchorus fascicularis Lamk. (Family: Tiliaceae). Indian Journal of Science and Technology 2: 34-35.
Palmer RG and Horner HT (2000) Genetics and cytology of a genic malesterile mutant form a transposon-containing soybean population. Journal of Heredity 91: 378-383.

Pankratz DG and Forsburg SL (2005) Meiotic S-phase damage activates recombination without checkpoint arrest. Molecular Biology of the Cell 16: 1651-1660.

Pierson BN, Bowling SE and Makaroff CA (1997) A defect in synapsis causes male sterility in a T-DNA-tagged Arabdopsis thaliana mutant. The Plant Journal 11: 659-669.

Prakken R (1943) Studies of asynapsis in rye. Hereditas 71: 475-495.

Rao KGR and Kumar OA (1983) Cytogenetics of a spontaneous desynaptic mutant in Chillies (Capsicum annum L).Cytologia 48: 195-199.

Rao SR and Kumar A (2003) Cytologia investigations in a desynaptic variant of Anogeissussericea var. sericea, an important hardwood tree of Rajasthan. Botanical Journal of Linnaeus Society 142: 103-110.

Reddi TVVS and Rao DRM (2000) Cytology of induced desynatic mutant in rice. Cytologia 65: 35-41.

Roeder GS(1997) Meiotic chromosomes: It takes two to tango. Genes and Development 11: 2600-2621.

Sharma RK and Reinbergs E (1974) Cytogenetic analysis of a desynaptic mutant in barley (Hordeumvulgare L.). Cytologia 39: 77-81.

Simchen G and Stamberg J (1969) Fine and coarse controls of genetic recombination. Nature 222: 329-332.

Singh S and Gupta PK (1981) Desynapsis in Zinnia haegena L. Cytologia 46: 63-67.

Soost RK (1951) Comparative cytology and genetics of asynaptic mutants in Lycopersicon esculentum L. Genetics 36: 410-434.

Srivastava HM (1974) Radiation induced desynaptic mutant in barley. Cytologia 39: 63-68.

Stebbins GL (1971) Chromosomal evolution in higher plants. Edward Arnold Publishers, London, 216p.

Zickler D and Kleckner N (1999) Meiotic chromosomes: integrating structure and function. Annual Review of Genetics 33: 603-754. 